\title{
EFEK PEMBERIAN EDUKASI HEALTH BELIEF MODEL PADA PENDERITA TUBERKULOSIS PARU TERHADAP PENGETAHUAN DAN PERSEPSI KEPATUHAN PENGOBATAN
}

Nevada Bilqis Patricia, Darjati, Suprijandani

Jurusan Kesehatan Lingkungan Poltekkes Kemenkes Surabaya Email: nevadabilais@gmail.com

\begin{abstract}
ABSTRAK
Indonesia memiliki salah satu negara berkembang yang berada di peringkat ke-3 dengan kasus infeksi tuberkulosis setelah Cina dan India. Jawa Timur adalah provinsi kedelapan dengan penemuan kasus TB paru BTA positif dan Kota Surabaya yang memiliki jumlah pasien tertinggi. Dari 62 pusat kesehatan kota di Surabaya, Pusat Kesehatan Simomulyo memiliki jumlah kematian tertinggi, 5 kasus. Salah satu upaya untuk meningkatkan angka kesembuhan adalah dengan mematuhi pengobatan dengan memberikan dukungan keluarga untuk memberikan dorongan psikologis. Tujuan dari penelitian ini adalah untuk mengetahui pengaruh penyediaan pendidikan dengan menggunakan teori pengetahuan dan persepsi Health Belief Model terhadap pengobatan TB paru.

Penelitian ini menggunakan one group pre post desain dengan jumlah sampel penelitian adalah 39 pasien TB paru. Teknik pengumpulan data adalah dengan observasi, wawancara dan kuesioner. Analisis data yang digunakan adalah analisis univariat dan bivariat menggunakan Paired T Test.

Hasil penelitian ini adalah bahwa ada perbedaan peningkatan rata-rata dalam pengetahuan dan persepsi sebelum dan sesudah diberikan pendidikan. Dengan hasil data dari uji $\mathrm{T}$ berpasangan menunjukkan angka $\mathrm{p}=0.000$ pada pengetahuan, persepsi kerentanan $p=0.000$, persepsi keseriusan $p=0.000$, persepsi manfaat dan hambatan $p$ $=0.000$ dan persepsi pengemudi $p=0.000$

Disimpulkan bahwa ada peningkatan perbedaan rata-rata dalam pengetahuan dan persepsi sebelum dan sesudah diberikan pendidikan. Bagi peneliti maka disarankan untuk menggunakan intervensi lain.
\end{abstract}

Kata Kunci: TB Paru, Health Belief Model, pengetahuan, persepsi kepatuhan

\section{PENDAHULUAN}

Berdasarkan sifat penularan penyakit dibagi menjadi penyakit menular dan tidak menular. Untuk proses penularan penyakit menular sendiri penyakit dapat terjadi karena interaksi antara agent penyebab penyakit dan dapat juga antara manusia dengan lingkungan. (Darmawan, Armadi. 2016)

Tuberkulosis (TBC) merupakan penyakit menular yang disebabkan oleh bakteri jenis Mycobacterium tuberculosis. Penyakit TBC ini dapat menyerang organ - organ tubuh sebagian besar yang terserang adalah organ paru - paru. Penyakit TBC paru ini jika tidak diobati atau pengobatan dilakukan tidak dengan teratur maka dapat membahayakan kesehatan penderita hingga menimbulkan komplikasi bahkan kematian (Infodatin, 2016). Tuberkulosis merupakan penyakit yang paling meresahkan masyarakat karena menjadi penyebab kematian ketiga terbesar setelah penyakit kardiovasikuler dan saluran pernafasan, tuberkulosis juga merupakan penyakit infeksi terbesar nomor satu (WHO dalam Muhtar, A.Haris. 2016)

Penularan kuman Mycobacterium tuberculosis sebagai penyebab penyakit TBC paru adalah dengan cara Droplet nuclei yaitu penyebaran kuman melalui udara yang mana kuman tersebut berada di percikan dahak pasien. (Pedoman Nasional Pengendalian Tuberkulosis, 2011). 
Dari laporan WHO Global Tuberculosis Report 2016 terdapat enam negara dengan menyumbang kasus baru sebanyak $60 \%$ dimana Indonesia juga termasuk di dalamnya. Dan juga Indonesia termasuk 20 negara dengan beban TBC tertinggi di dunia dengan perkiraan jumlah kasus yang terhitung pada tahun 2015 sebanyak $87 \%$ - 92\%. Di seluruh dunia tingkat penurunan TBC pada tahun 2014-2015 tetap yaitu hanya $1,5 \%$.

Indonesia adalah salah satu negara berkembang yang termasuk pada kasus yang terinfeksi tuberkulosis dimana Indonesia menempati peringkat ketiga setelah negara Cina dan India. Departemen Kesehatan RI memperkirakan setiap tahunnya sebanyak 528.000 kasus baru yang terdapat di Indonesia. (Sari, Ida Diana. Dkk, 2016).

Pada tahun 2014 provinsi Jawa Timur menempati urutan kedelapan dari seluruh provinsi di Indonesia dengan penemuan kasus BTA positif yaitu sebanyak 21.036 penderita dan pada data pada tahun 2013 pasien yang telah diobati dengan angka kesembuhan mencapai target yang telah ditentukan yaitu 85\% (Puspitasari. Dkk. 2107).

Puskesmas Simomulyo menjadi urutan ke 10 penderita tebanyak di Kota Surabaya. Dari 10 urutan puskesmas yang memiliki data penderita terbanyak yang mempunyai tingkat kesembuhan paling sedikit adalah Puskesmas Perak timur selain itu terdapat juga Puskesmas Simomulyo dengan angka kesembuhan rendah yaitu sebesar $56,76 \%$, angka pengobatan lengkap sebesar $24,32 \%$, angka keberhasilan pengobatan sebesar $81,08 \%$, angka drop out pengobatan sebanyak $6 \%$ dengan jumlah kematian 5 pasien.

Program penanggulangan tuberkulosis paru salah satunya adalah dengan memberikan penyuluhan kesehatan dimana penyuluhan sendiri adalah prosedur kegiatan yang menjelaskan tentang prinsip-prinsip belajar dalam kehidupan untuk individu atau masyarakat dalam mencapai gaya hidup sehat dengan cara pemeliharaan, melindungi dalam meningkatkan kesehatan (Liestyowati, 2008).

Menurut teori Health Belief Model (HBM) individu melakukan tindakan kesehatan seperti melakukan pengobatan dan pencegahan untuk meningkatkan status kesehatan yang dipengaruhi oleh faktor - faktor seperti kerentanan pada penyakit, keseriusan yang dirasakan, manfaat yang dirasakan, penghalang yang dirasakan dan kepercayaan seseorang untuk melakukan perilaku sehat. Tujuan penelitian ini untuk mengetahui hubungan pemberian edukasi Health Belief Model (HBM) pada tingkat pengetahuan dan presepsi penderita tuberkulosis paru terhadap kepatuhan pengobatan.

\section{METODE PENELITIAN}

Penelitian yang digunakan adalah jenis observasional jenis rancangan penelitian yang digunakan adalah penelitian eksperimen one group prepost test design yaitu pengukuran yang dilakukan pada satu kelompok subjek dan dilakukan pengukuran sebelum dan sesudah pemberian perlakuan pada kelompok subjek tersebut. Besar populasi sebanyak 65 penderita dengan jumlah sampel sebanyak 39 penderita. Variabel bebas dalam penelitian ini adalah pemberian edukasi health belief model dan variabel terikat adalah pengetahuan dan persepsi penderita.

Teknik pengumpulan data dengan cara observasi, wawancara dan pengisian kuisioner. Penilaian dengan menggunakan uji paired $T$ test.

\section{HASIL PEMBAHASAN}

\section{Tabel 1}

HASIL PRETEST PENGETAHUAN

\begin{tabular}{cccccc}
\hline & Frekuensi & Persen & $\begin{array}{c}\text { Valid } \\
\text { Persen }\end{array}$ & $\begin{array}{c}\text { Cumulative } \\
\text { Persen }\end{array}$ \\
\hline Cukup & 17 & $43,6 \%$ & $43,6 \%$ & $53,6 \%$ \\
\hline Valid & Baik & 22 & $56,4 \%$ & $56,4 \%$ & $100 \%$ \\
\hline & Total & 39 & 100 & 100 & \\
\hline
\end{tabular}


GEMA Lingkungan Kesehatan

VOL 18 NO 1 JANUARI 2020

Tabel 2

HASIL POSTTEST PENGETAHUAN

\begin{tabular}{cccccc}
\hline & & Frekuensi & Persen & $\begin{array}{c}\text { Valid } \\
\text { Persen }\end{array}$ & $\begin{array}{c}\text { Cumulative } \\
\text { Persen }\end{array}$ \\
\hline & Cukup & 4 & $10,3 \%$ & $10,3 \%$ & $10,3 \%$ \\
\hline Valid & Baik & 35 & $89,7 \%$ & $89,7 \%$ & $100 \%$ \\
\hline & Total & 39 & 100 & 100 & \\
\hline
\end{tabular}

Tabel 3

HASIL PAIRED T TEST PENGETAHUAN

\begin{tabular}{|c|c|c|c|c|c|c|c|c|c|}
\hline & \multicolumn{5}{|c|}{ Paired Differences } & \multirow{3}{*}{$t$} & \multirow{3}{*}{ df } & \\
\hline & & \multirow[t]{2}{*}{ Mean } & \multirow[t]{2}{*}{$\begin{array}{c}\text { Std. } \\
\text { Deviation }\end{array}$} & \multirow[t]{2}{*}{$\begin{array}{l}\text { Std. } \\
\text { Error } \\
\text { Mean }\end{array}$} & \multicolumn{2}{|c|}{$\begin{array}{c}95 \% \\
\text { Confidence } \\
\text { Interval of the } \\
\text { Difference }\end{array}$} & & & $\begin{array}{c}\text { Sig. } \\
(2- \\
\text { tailed })\end{array}$ \\
\hline \multirow{2}{*}{$\begin{array}{c}\text { Pair } \\
1\end{array}$} & \multirow{2}{*}{$\begin{array}{c}\text { Pengetahuan } \\
\text { pretest dan } \\
\text { posttest }\end{array}$} & & & & Lower & Upper & & & \\
\hline & & -.333 & .478 & .076 & -.488 & -.179 & $\begin{array}{c}- \\
4.359 \\
\end{array}$ & 38 & .000 \\
\hline
\end{tabular}

Dari penilaian pengetahuan pada pre test yang dilakukan penderita tuberkulosis paru BTA+ di Puskesmas Simomulyo didapatkan hasil dengan kategori cukup sebanyak 17 orang dengan jumlah persentase $43,6 \%$, kemudian kategori baik sebanyak 22 orang dengan persentase 56,4\%. Dan pengetahuan saat post test terdapat sebanyak 4 pasien dengan penilaian cukup dan persentase $10,3 \%$, kemudian sebanyak 35 orang dengan kategori baik dengan persentase $89,7 \%$.

Hasil uji paired $T$ test menunjukkan perbedaan peningkatan rata-rata dari pengetahuan sebelum dan sesudah sebesar 0,333. Dikarenakan nilai Sig.(2tailed) pada hasil uji mendapatkan nilai 0,000 yang mana artinya ada perbedaan dari hasil pre dan post test.

Dari hasil tersebut dapat dilihat jika hampir keseluruhan pasien penderita tuberkulosis paru memiliki pengetahuan yang cukup baik terhadap penyakit tuberkulosis. Dari hasil sharing yang dilakukan hampir keseluruhan pasien yang menderita tuberkulosis mengetahui penyakit tuberkulosis dari poster yang ditempel pada dinding puskesmas. Selain itu, pasien juga antusias mengetahui penyakit ini dari kegiatan konsultasi yang dilakukan juga ada yang mencari tahu tentang tuberkulosis dari media internet.

Informasi yang diberikan baik melalui penyuluhan ataupun dengan media seperti poster, leaflet, video sangat mempengaruhi tingkat pengetahuan seseorang.
Media poster dan leaflet sebagai penyebaran informasi dapat memberikan efek untuk peningkatan pengetahuan dari seseorang, hal ini dikarenakan poster atau leaflet yang memiliki isi yang dapat menarik perhatian dari individu bisa membentuk suatu pengetahuan, pandangan persepsi dan sikap (Linasari, 2017).

Muhammad Yusuf Bachtiar (2015) dalam penelitiannya menyatakan terdapat peningkatan pengetahuan yang diberikan pada kelompok siswa yang mendapatkan Pendidikan dengan metode ceramah dengan menggunakan media leaflet. Dimana media lealet juga menjadi penudukung untuk memperjelas dari pemberian Pendidikan dengan melalui ceramah.

Kenaikan tingkat pengetahuan dari penderita TBC paru dapat dilihat karena kemauan dari penderita TBC untuk mencari tahu tentang penyakit tuberkulosis dan antusiasme dari penderita saat melakukan konseling, juga dapat berasal dari pengalaman pribadi yang melihat keadaan sekitar tentang keluarga, teman atau tetangga yang mengalami atau terserang penyakit tuberkulosis. Selain itu pengetahuan dapat semakin meningkat setelah diberikan edukasi yang mana edukasi dapat menunjang untuk penambahan wawasan dari seseorang.

Sesuai dengan UU No. 36 tahun 2019 dimana penyuluhan dilakukan untuk meningkatkan pengetahuan, kemauan, kesaran dari masyarakat untuk dapat hidup sehat. Selain itu, penyuluhan juga diberikan dalam bentuk pendekatan komunikasi agar dapat mengubah suatu pola pikir dan perilaku baik dari perorangan maupun kelompok (Rotua Lenawati, 2016)

Menurut Notoadmojo (2012) cara mendapatkan pengetahuan salah satunya dengan berdasarkan pengalaman pribadi. Dimana pengetahuan diperoleh dengan dilakukannya pengulangan dari pemecahan masalah yang ada. 
Tabel 4

HASIL PRE TEST PERSEPSI KERENTANAN

\begin{tabular}{cccccc}
\hline & Frekuensi & Persen & $\begin{array}{c}\text { Valid } \\
\text { Persen }\end{array}$ & $\begin{array}{c}\text { Cumulative } \\
\text { Persen }\end{array}$ \\
\hline Valid & Cukup & 35 & $89,7 \%$ & $89,7 \%$ & $89,7 \%$ \\
\hline & Baik & 4 & $10,3 \%$ & $10,3 \%$ & $100 \%$ \\
\hline & Total & 39 & 100 & 100 & \\
\hline
\end{tabular}

Tabel 5

HASIL POST TEST PERSEPSI KERENTANAN

\begin{tabular}{cccccc}
\hline & & Frekuensi & Persen & $\begin{array}{c}\text { Valid } \\
\text { Persen }\end{array}$ & $\begin{array}{c}\text { Cumulative } \\
\text { Persen }\end{array}$ \\
\hline & Cukup & 14 & $35,9 \%$ & $35,9 \%$ & $35,9 \%$ \\
\hline Valid & Baik & 25 & $64,1 \%$ & $64,1 \%$ & $100 \%$ \\
\hline & Total & 39 & 100 & 100 & \\
\hline
\end{tabular}

Tabel 6

HASIL PAIRED T TEST PERSEPSI KERENTANAN

\begin{tabular}{|c|c|c|c|c|c|c|c|c|c|}
\hline & & \multicolumn{5}{|c|}{ Paired Differences } & \multirow{3}{*}{ T } & \multirow{3}{*}{ df } & \multirow{3}{*}{$\begin{array}{c}\text { Sig. } \\
(2- \\
\text { tailed) }\end{array}$} \\
\hline & & \multirow[t]{2}{*}{ Mean } & \multirow[t]{2}{*}{$\begin{array}{c}\text { Std. } \\
\text { Deviation }\end{array}$} & \multirow[t]{2}{*}{$\begin{array}{l}\text { Std. } \\
\text { Error } \\
\text { Mean }\end{array}$} & \multicolumn{2}{|c|}{$\begin{array}{c}95 \% \\
\text { Confidence } \\
\text { Interval of the } \\
\text { Difference }\end{array}$} & & & \\
\hline & Terent? & & & & Lower & Upper & & & \\
\hline $\begin{array}{c}\text { Pair } \\
1\end{array}$ & $\begin{array}{c}\text { kerentanan } \\
\text { pretest dan } \\
\text { posttest }\end{array}$ & -.538 & .505 & .081 & -.702 & -.375 & $6 .-$ & 38 & .000 \\
\hline
\end{tabular}

Dari penialain persepsi kerentanan yang dirasakan oleh penderita tuberkulosis paru mendapatkan hasil kategori cukup sebanyak 35 orang dengan persentase $89,7 \%$, untuk kategori baik sebanyak 4 orang dengan persentase 10,3\%. Hasil penilaian persepsi kerentanan pada post test di dapatkan hasil dengan kategori cukup sebanyak 14 orang dengan persentase $35,9 \%$ dan hasil ketgori baik sebanyak 25 orang dengan persentase $64,1 \%$.

Perbedaan peningkatan rata-rata persepsi kerentanan sebesar 0,538. Dikarenakan nilai Sig.(2-tailed) pada hasil uji mendapatkan nilai 0,000 yang mana artinya ada perbedaan dari hasil pre dan post test.

Persepsi kerentanan sendiri adalah anggapan bahwa seseorang merasa adanya risiko terserang suatu penyakit sehingga melakukan tindakan pencegahan atau pengobatan.

Masing-masing individu sebenarnya sudah mempunyai pandangan dimana jika kondisi tubuh mereka tidak dalam keadaan dengan stamina yang tinggi maka mereka akan dapat dengan mudah terserang penyakit. Sehingga dari yang merasakan rentan akan terserang penyakit maupun takut jika tidak melakukan pengobatan maka akan membuat penyakit menjadi parah.

Pemberian edukasi untuk penderita dapat menambahkan rasa mawas diri atau motivasi agar sembuh dan terhindar terhadap suatu penyakit selain itu, dapat merubah pandangan terhadap suatu penyakit.

Notoatmodjo (2003) individu akan melakukan tindakan pencegahan maupun pengobatan jika individu tersebut merasakan kerentanan terhadap suatu penyakit.

Iis Nurhayati (2015) menyatakan bahwa semakin tinggi persepsi penderita tuberculosis akan penyebaran dan akibat yang ditimbulkan jika tidak melakukan pengobatan maka semakin meningkatkan pula perilaku dari penderita untuk menghindari kemungkinan buruk terjadi.

Tabel 7

HASIL PRE TEST PERSEPSI KESERIUSAN

\begin{tabular}{|c|c|c|c|c|c|}
\hline & & Frekuensi & Persen & $\begin{array}{l}\text { Valid } \\
\text { Persen }\end{array}$ & $\begin{array}{c}\text { Cumulative } \\
\text { Persen }\end{array}$ \\
\hline & Kurang & 2 & $5,1 \%$ & $5,1 \%$ & $5,1 \%$ \\
\hline & Cukup & 27 & $69,2 \%$ & $69,2 \%$ & $74,4 \%$ \\
\hline \multirow[t]{5}{*}{ Valid } & Baik & 10 & $25,6 \%$ & $25,6 \%$ & $100 \%$ \\
\hline & Total & 39 & 100 & 100 & \\
\hline & HASIL & $\begin{array}{l}\text { Tabel } \\
\text { OST TES } \\
\text { KESERIU }\end{array}$ & $\begin{array}{l}\mathbf{8} \\
\text { T PERS } \\
\text { SAN }\end{array}$ & EPSI & \\
\hline & & Frekuensi & Persen & $\begin{array}{l}\text { Valid } \\
\text { Persen }\end{array}$ & $\begin{array}{c}\text { Cumulative } \\
\text { Persen }\end{array}$ \\
\hline & Cuknp & 9 & $23,1 \%$ & $23,1 \%$ & $23,1 \%$ \\
\hline \multirow[t]{2}{*}{ Valid } & Baik & 30 & $76,9 \%$ & $76,9 \%$ & $100 \%$ \\
\hline & Total & 39 & 100 & 100 & \\
\hline
\end{tabular}

Tabel 9

HASIL UJI PAIRED T TEST PERSEPSI KESERIUSAN

\begin{tabular}{|c|c|c|c|c|c|c|c|c|c|}
\hline & \multicolumn{5}{|c|}{ Paired Differences } & \multirow{3}{*}{$\mathrm{T}$} & \multirow{3}{*}{ df } & \multirow{3}{*}{$\begin{array}{c}\text { Sig. } \\
(2- \\
\text { tailed })\end{array}$} \\
\hline & & \multirow[t]{2}{*}{ Mean } & \multirow[t]{2}{*}{$\begin{array}{c}\text { Std. } \\
\text { Deviation }\end{array}$} & \multirow{2}{*}{$\begin{array}{c}\text { Std. } \\
\text { Error } \\
\text { Mean }\end{array}$} & \multicolumn{2}{|c|}{$\begin{array}{l}95 \% \text { Confidence } \\
\text { Interval of the } \\
\text { Difference }\end{array}$} & & & \\
\hline \multirow{2}{*}{$\begin{array}{c}\text { Pair } \\
1\end{array}$} & Persepsi & & & & Lower & Upper & & & \\
\hline & $\begin{array}{c}\text { pre test dan } \\
\text { post test }\end{array}$ & -.564 & .598 & .096 & -.758 & -.370 & $-5,891$ & 38 & .000 \\
\hline
\end{tabular}

Persepsi keseriusan penderita tuberkulosis paru yang mendapatkan hasil dengan kategori kurang sebanyak 2 orang dengan jumlah persentase 5,1\%, kategori cukup sebanyak 27 orang dengan persentase 69,25\% dan kategori baik sebanyak 10 orang dengan persentase $25,6 \%$. persepsi keseriusan pada post test mendaptkan hasil dengan 
kategori cukup sebanyak 9 orang dengan persentase $23,1 \%$, dan kategori baik 30 orang dengan persentase $76,9 \%$.

Perbedaan peningkatan rata-rata dari persepsi keseriusan sebesar 0,564. disimpulkan jika ada perbedaan rata-rata antara persepsi keseriusan pada pre test dan post test.

Persepsi keseriusan adalah anggapan di mana seorang individu yang melakukan pengobatan, tindakan pencegahan karena merasakan bahwa keseriusan dampak dari terserangnya suatu penyakit hingga dapat menyebabkan kematian.

Keseriusan yang dirasakan individu dapat mendorong individu untuk melakukan pengobatan dengan patuh dan lengkap. Penderita dengan persepsi keseriusan yang rendah dapat saja dikarenakan sudah merasakan kondisi yang lebih baik setelah mengkonsumsi obat dan mengabaikan untuk mengkonsumsi obat secara terartur dan lengkap.

Dengan memberikan edukasi pada penderita juga dapat memberikan efek peningkatan persepsi keseriusan individu, sehingga dapat menjadi faktor peningkatan untuk melakukan pengobatan.

Peningkatan persepsi keseriusan dapat berasal dari informasi yang diperoleh baik berasal dari dokter maupun hal pendukung lainnya, selain informasi juga dapat berasal dari besarnya suatu masalah yang sedang dihadapi (Zahrotun Ulum, 2015).

Tabel 10

HASIL PRE TEST PERSEPSI MANFAAT DAN HAMBATAN

\begin{tabular}{|c|c|c|c|c|c|}
\hline & & Frekuensi & Persen & $\begin{array}{c}\text { Valid } \\
\text { Persen }\end{array}$ & $\begin{array}{l}\text { Cumulative } \\
\text { Persen }\end{array}$ \\
\hline & Kurang & 3 & $7,7 \%$ & $7,7 \%$ & $7,7 \%$ \\
\hline & Cukup & 18 & $46,2 \%$ & $46,2 \%$ & $53,8 \%$ \\
\hline \multirow[t]{2}{*}{ Valid } & Baik & 18 & $46,2 \%$ & $46,2 \%$ & $100 \%$ \\
\hline & Total & 39 & 100 & 100 & \\
\hline
\end{tabular}

Hasil penilian pre test persepsi manfaat dan hambatan pasien didapatkan bahwa sebanyak 3 orang dengan hsil penilaian kurang dengan jumlah persentase $7,7 \%$, 18 orang dengan hasil penilaian cukup jumlah persentas $46,2 \%$ dan kategori baik sebanyak 18 orang dengan persentase $46,2 \%$. penilaian post test persepsi manfaat dan hambatan dari pasien tuberkulosis paru adalah sebanyak 3 orang dengan mendaptkan hasil cukup dengan jumlah persentase $7,7 \%$, kemudian sebanyak 36 orang yang mendaptakan hasil baik dengan jumlah persentase sebesar $92,3 \%$.

Tabel 11

HASIL POST TEST PERSEPSI MANFAAT DAN HAMBATAN

\begin{tabular}{cccccc}
\hline & Frekuensi & Persen & $\begin{array}{c}\text { Valid } \\
\text { Persen }\end{array}$ & $\begin{array}{c}\text { Cumulative } \\
\text { Persen }\end{array}$ \\
\hline Cukup & 3 & $7,7 \%$ & $7,7 \%$ & $7,7 \%$ \\
\hline Valid & Baik & 36 & $92,3 \%$ & $92,3 \%$ & $100 \%$ \\
\hline & Total & 39 & 100 & 100 & \\
\hline
\end{tabular}

Tabel 12

HASIL UJI WILCOXSON MANFAAT DAN HAMBATAN

\begin{tabular}{cc}
\hline & $\begin{array}{c}\text { Manfaat dan } \\
\text { hambatan pretest } \\
\text { dan posttest }\end{array}$ \\
\hline A & -5.025 \\
\hline Asymp. Sig. (2-tailed) & .000 \\
\hline
\end{tabular}

Dikarenakan nilai Sig. (2-tailed) pada hasil uji mendapatkan nilai 0,000 yang mana artinya $\mathrm{H} 1$ diterima sehingga ada perbedaan dari hasil pre dan post test persepsi manfaat dan hambatan.

Persepsi manfaat dan hambatan adalah individu akan melakukan hal-hal yang bisa membawa ke dampak lebih baik atau positif meskipun juga terdapat rintangan pada saat melagsungkan kegiatan tersebut.

Hambatan yang dirasakan dari penderita kemungkinan bisa berasal dari lama waktu pengkonsumsian obat, selain itu juga efek samping dari obat. Akan tetapi masih bisa dirasakan manfaat dalam pengkonsumsian obat secara taratur.

Firman Maulana Safri (2013) salah satu faktor yang dapat mempengaruhi patuh atau tidaknya penderita dalam mengkonsumsi obat adalah pengalaman peribadi saat mengkonsumsi obat.

Peningkatan manfaat dan hambatan yang dirasakan dapat berasal dari pengalaman peribadi masing-masing individu. Terdapat beberapa penderita 
yang kambuh terserang penyakit tuberculosis.

Bastable (2003) menyatakan bahwa salah satu kebutuhan yang mendorong untuk melakukan tindakan dipengaruhi beberapa hal yang mempengaruhi persepsi seperti pengalaman pribadi, perbedaan budaya (Firman Maulana, 2013)

Tabel 13

HASIL PRE TEST PERSEPSI PENDORONG

\begin{tabular}{rccccc}
\hline & Frekuensi & Persen & $\begin{array}{c}\text { Valid } \\
\text { Persen }\end{array}$ & $\begin{array}{c}\text { Cumulative } \\
\text { Persen }\end{array}$ \\
\hline Kurang & 10 & $25,6 \%$ & $25,6 \%$ & $25,6 \%$ \\
\hline Cukup & 23 & $59,0 \%$ & $59,0 \%$ & $84,6 \%$ \\
\hline & Baik & 6 & $15,4 \%$ & $15,4 \%$ & $100 \%$ \\
\hline & Total & 39 & 100 & 100 & \\
\hline
\end{tabular}

Tabel 14

HASIL POST TEST PERSEPSI PENDORONG

\begin{tabular}{rccccc}
\hline & Frekuensi & Persen & $\begin{array}{c}\text { Valid } \\
\text { Persen }\end{array}$ & $\begin{array}{c}\text { Cumulative } \\
\text { Persen }\end{array}$ \\
\hline Kurang & 1 & $2,6 \%$ & $2,6 \%$ & $2,6 \%$ \\
\hline Valid & Cukup & 18 & $46,2 \%$ & $46,2 \%$ & $48,7 \%$ \\
\hline & Baik & 20 & $51,3 \%$ & $51,3 \%$ & $100 \%$ \\
\hline & Total & 39 & 100 & 100 & \\
\hline
\end{tabular}

Tabel 15

HASIL UJI WILCOXSON PERSEPSI PENDORONG

\begin{tabular}{cc}
\hline & $\begin{array}{c}\text { Manfaat dan } \\
\text { hambatan pretest } \\
\text { dan posttest }\end{array}$ \\
\hline Asymp. Sig. (2-tailed) & -5.025 \\
\hline Pada hasil pre test persepsi
\end{tabular}

pendorong yang mendapatkan ketegori kurang sebanyak 10 orang jumlah persentase $25,6 \%, 23$ orang dengan hasil kategori cukup jumlah persentase $59 \%$ dan sebanyak 6 orang dengan kategori baik dengan jumlah persentase $15,4 \%$. penilaian post test persepsi pendorong terdapat sebanyak 1 orang yang mendapatkan kategori kurang dengan jumlah persentase 2,6\%, 18 orang dengan hasil kategori cukup jumlah persentase $46,2 \%$ dan 20 orang dengan kategori baik jumlah persentase $51,3 \%$.

Nilai Sig. (2-tailed) pada hasil uji mendapatkan nilai 0,000 yang mana artinya $\mathrm{H} 1$ diterima sehingga ada perbedaan dari hasil pre dan post test persepsi pendorong.
Persepsi pendorong yaitu dimana anggapan dari individu untuk mencari lebih dalam akan suatu hal contohnya dikhususkan dalam informasi penyakit sehinga individu daapat menerima informasi yang benar akan kerentanan terserang suatu penyakit, keseriusan, manfaat dan hambatan dalam suatu tindakan.

Persepsi pendorong yang dirasakan adalah mersakan pentingnya mendatkan suatu dukungan atau informasi dari sekitar sehingga dapat mendorong individu untuk melakukan hal yang lebih baik yaitu melakukan pengobatan.

Persepsi pendorong bisa didapatkan dari internal maupun eksternal yaitu dapat berupa hal-hal pendukung kesehatan baik melalui konsultasi, media masa, anjuran teman. Selain itu faktor internal dapat berasal dari pengetahuan masing-masing individu dan motivasi yang ada dalam dirina (Iis Nurhayati, 2015).

Terjadi peningkatan persepsi pendorong dari pasien penderita tuberkulosis dimana mereka mulai merasakan pentingnya mendapatkan informasi, perlunya dukungan sekitar sebagai pendorong untuk melakukan kegiatan yang lebih baik.

Informasi yang didapatkan dari keadaan sekitar akan lebih mudah diterima oleh seseorang sehingga dapat mempengaruhi pengeetahuan dan persepsi dari individu.

\section{KESIMPULAN}

1. Rata-rata penderita memiliki tingkat pengetahuan sebelum diberikan edukasi yang cukup.

2. Pengetahuan penderita setelah diberikan edukasi meningkat.

3. Persepsi kerentanan dari pasien sebelum diberikan edukasi sebagian besar memiliki persepsi yang cukup baik dan setelah diberikan edukasi persepsi kerentanan yang baik.

4. Persepsi keseriusan terdapat peningkatan dimana sebelum diberikan edukasi sebagian besar merasakan keseriusan yang cukup dan setelah diberikan edukasi mengalami peningkatan yang 
sebagian besar merasakan keseriusan yang baik.

5. Rata-rata dari persepsi manfaat dan hambatan yang dirasakan oleh penderita tuberkulosis paru sebelum diberikan edukasi mengalami peningkatan sebelum dan sesudah diberikan edukasi.

6. Persepsi pendorong setelah diberikan edukasi sebagian besar menyadari memerlukan pendorong untuk melakukan kegiatan yang lebih baik dengan adanya informasi baik dari tenaga kesehatan maupun internet.

\section{SARAN}

Puskesmas penyuluhan dapat mengadakan terhadap penderita tuberkulosis paru dengan materi yang menggunakan pendekatan HBM (Health Belief Model) serta melakukan kunjungan rutin pada penderita tuberkulosis terutama untuk pengobatan.

\section{DAFTAR PUSTAKA}

Dinas Kesehatan Pemerintah Kota Surabaya. 2017. Profil Kesehatan 2017. Surabaya

Dinas Kesehatan Provinsi Jawa Timur. 2017. Profil kesehtan Provinsi Jawa Timur Tahun 2016. Surabaya.

Kementerian Kesehatan RI. 2013. Pedoman Nasional Pelayanan Kedokteran Tata Laksana Tuberkulosis. Jakarta.

Kementrian Kesehatan Republik Indonesia. 2014. Pedoman Nasional Pengendalian Tuberkulosis. Jakarta: Kementerian Kesehatan RI.
Linasari. 2017. Pengaruh Penggunaan Media Poster dan Leaflet terhadap Pengetahuan Siswa SMA di Bandar Lampung Tentang Karies Gigi. Tanjungkarang : Jurnal keperawatan, Vlumer XIII, no 1 April 2017.

Perhimpunan Dokter Paru Indonesia. 2006. Pedoman Diagnosis \& Penatalaksanaan di Indoensia. PDPI.

Pusat Data dan Informasi Kemneterian Kesehatan RI. 2015. Tuberkulosis Temukan Obati Sampai Sembuh.

Pusat Data dan Informasi Kemneterian Kesehatan RI. 2016. Tuberkulosis Temukan Obati Sampai Sembuh

Puspitasari. Dkk. 2017. Effects of Education, Nutrition Status, Treatment Compliance, Family Income, and Family Support, on the Cure of Tuberculosis in Mojokerto, East Java. Journal of Epidemiology and Public Health e-ISSN : 25490273

Sari, Ida Diana. Dkk. 2016. Hubungan Pengetahuan dan Sikap dengan Kepatuhan Berobat pada Pasien TB Paru yang Rawat Jalan di Jakarta Tahun 2014. Jakarta: Balitbangkes, Kemenkes RI.

Undang - undang Republik Indonesia no 36 Tahun 2009 tentang Kesehatan. 